\title{
Kordia periserrulae sp. nov., isolated from a marine polychaete Periserrula leucophryna, and emended description of the genus Kordia
}

Correspondence Jang-Cheon Cho chojc@inha.ac.kr
Ahyoung Choi, Hyun-Myung Oh, Seung-Jo Yang and Jang-Cheon Cho

Division of Biology and Ocean Sciences, Inha University, Incheon 402-751, Republic of Korea
The genus Kordia (Sohn et al., 2004), a member of the family Flavobacteriaceae (Bernardet et al., 2002; Bernardet \& Nakagawa, 2006), currently comprises only the type species, Kordia algicida. The type strain of Kordia algicida was isolated from a surface seawater sample from Masan Bay, Korea, and was characterized as being Gram-stainingnegative, yellow-pigmented, non-motile, flexirubin-negative and strictly aerobic with rod-shaped cells. Menaquinone 6 (MK-6) was the predominant isoprenoid quinone and the DNA G + C content of the type strain was $34 \mathrm{~mol} \%$ (Sohn et al., 2004). At the time of publication of the name Kordia algicida (Sohn et al., 2004), the type strain, OT- $1^{\mathrm{T}}$, was deposited in two culture collections in two different countries. However, the strain was deposited in the KCTC (Korean Collection for Type Cultures) as a patent strain, designated KCTC $8814 \mathrm{P}^{\mathrm{T}}$. According to Rule 30 (4) of the Bacteriological Code (Tindall et al., 2008), organisms deposited in such a fashion that access is restricted, such as safe deposits or strains deposited solely for current patent purposes, may not serve as type strains. This ruling meant that the genus name Kordia and species name Kordia algicida were not regarded as having been validly published. Recently strain OT- $1^{\mathrm{T}}$ was deposited in the KACC (Korean Agricultural Culture Collection) as KACC $15108^{\mathrm{T}}$, which now fulfils the criteria for valid publication of the name Kordia algicida. In the present study, based on a polyphasic approach, we describe strain IMCC $1412^{\mathrm{T}}$, which was

The GenBank/EMBL/DDBJ accession number for the 16S rRNA gene sequence of strain IMCC $1412^{\top}$ is GU233518.

A supplementary figure is available with the online version of this paper. isolated from a marine polychaete dwelling in a tidal flat. The results of phenotypic and genotypic characterization indicate that strain $\mathrm{IMCC} 1412^{\mathrm{T}}$ represents a novel species in the genus Kordia.

Strain IMCC $1412^{\mathrm{T}}$ was isolated from the digestive tract of a marine polychaete, Periserrula leucophryna, collected from a tidal flat on Donggum Island. The marine animal was washed with sterile seawater three times and dissected under a stereoscopic microscope (SZH10; Olympus). The contents of the digestive tract were homogenized and serially diluted samples were spread onto an oligotrophic medium, R2A agar (BD Difco) diluted 1:10 (v/v) with aged seawater (1/10 R2A medium), and the plates were incubated aerobically at $20{ }^{\circ} \mathrm{C}$ for 1 month. After the optimum growth temperature of the strain had been determined, the strain was routinely grown on marine agar 2216 (MA; BD Difco) at $30{ }^{\circ} \mathrm{C}$. For phenotypic and chemotaxonomic comparisons between strain IMCC1412 and $K$. algicida, strain KCTC $8814 \mathrm{P}^{\mathrm{T}}$ was obtained from the KCTC with the permission of Dr Sang-Jin Kim (the depositor of the strain) and used as a reference strain in the taxonomic study.

Genomic DNA preparation, 16S rRNA gene amplification and sequencing were performed as described previously (Cho \& Giovannoni, 2003). The resulting almost-complete $16 \mathrm{~S}$ rRNA gene sequence $(1474 \mathrm{bp})$ of strain IMCC $1412^{\mathrm{T}}$ was aligned with the nearest neighbours using the ARB software package (Ludwig et al., 2004) and unambiguously aligned nucleotide positions were used for phylogenetic analyses in PAUP ${ }^{\star} 4.0$ beta (Swofford, 2002). The $16 \mathrm{~S}$ rRNA 
gene sequence similarities between strain IMCC $1412^{\mathrm{T}}$ and its phylogenetic relatives were determined using the ARB package and also confirmed by accessing the EzTaxon server (Chun et al., 2007). Phylogenetic trees were generated using neighbour-joining (Saitou \& Nei, 1987) with the Jukes-Cantor distance formula (Jukes \& Cantor, 1969), maximum-parsimony (Fitch, 1971) and maximum-likelihood (Felsenstein, 1981) methods. The robustness of the neighbour-joining and maximum-parsimony trees was confirmed by bootstrap analyses based on 1000 resamplings of the sequences. Based on $16 \mathrm{~S}$ rRNA gene sequence comparisons, strain IMCC $1412^{\mathrm{T}}$ was related most closely to $K$. algicida $\mathrm{KCTC} 8814 \mathrm{P}^{\mathrm{T}}(96.7 \%)$, followed by Aquimarina latercula ATCC $23177^{\mathrm{T}}(91.6 \%)$ and Psychroserpens mesophilus KOPRI $13649^{\mathrm{T}}(91.3 \%)$. In all the phylogenetic trees (Fig. 1), strains IMCC $1412^{\mathrm{T}}$ and K. algicida KCTC $8814 \mathrm{P}^{\mathrm{T}}$ formed a robust monophyletic clade with a high bootstrap value $(100 \%)$, indicating the strain belonged to the genus Kordia. DNA-DNA hybridization experiments as suggested by Wayne et al. (1987) for the determination of bacterial species were not performed because the 16S rRNA gene sequence similarity between strain $\mathrm{IMCC} 1412^{\mathrm{T}}$ and $K$. algicida was $<97 \%$ (Stackebrandt \& Goebel, 1994). The phylogenetic results coupled with the 16S rRNA gene sequence analyses suggested that strain IMCC $1412^{\mathrm{T}}$ should be assigned to the genus Kordia as representing a novel species.

For phenotypic characterization, strains $\mathrm{IMCC} 1412^{\mathrm{T}}$ and K. algicida KCTC $8814 \mathrm{P}^{\mathrm{T}}$ were routinely grown on MA at $30{ }^{\circ} \mathrm{C}$. All the phenotypic tests, except for determination of temperature range and optimum for growth, were performed at $30{ }^{\circ} \mathrm{C}$. Morphology and size of the cells and colonies, Gram reaction, presence of flagellar and gliding motilities, catalase and oxidase activities, presence of flexirubin-type pigments and the absorption spectra of cellular pigments were determined by the methods described by Yang \& Cho (2008) and Bernardet et al. (2002) except that the bacterial cultures were grown on MA or in marine broth ( $\mathrm{MB}, \mathrm{BD}$ Difco) at $30{ }^{\circ} \mathrm{C}$ for 3 days. The temperature range and optimum for growth were determined on MA that was incubated at $4-42{ }^{\circ} \mathrm{C}(4,10$, $15,20,25,30,37$ and $42{ }^{\circ} \mathrm{C}$ ). The $\mathrm{pH}$ range and optimum for growth were examined from $\mathrm{pH} 4.0$ to 12.0 (at $0.5 \mathrm{pH}$ unit intervals) in $\mathrm{MB}$. The $\mathrm{pH}$ was adjusted with $0.1 \mathrm{M}$ $\mathrm{HCl}$ or $0.1 \mathrm{M} \mathrm{Na}_{2} \mathrm{CO}_{3}$. The range and optimum $\mathrm{NaCl}$ concentration for growth were determined in $\mathrm{NaCl}$-free artificial seawater medium (ASW, Choo et al., 2007) amended with $5.0 \mathrm{~g}$ peptone, $1.0 \mathrm{~g}$ yeast extract and various concentrations of $\mathrm{NaCl}(0-15 \%, \mathrm{w} / \mathrm{v})$. Anaerobic growth was tested on MA using the MGC anaerobic system (Mitsubishi Gas Chemical) for 3 weeks. Production of $\mathrm{H}_{2} \mathrm{~S}$ was investigated using triple-sugar iron agar (BD Difco) in which the salinity was adjusted with $3.0 \%(\mathrm{w} / \mathrm{v}) \mathrm{NaCl}$. Hydrolysis of casein ( $10 \%$ skimmed milk, w/v), starch $(0.2 \%, \mathrm{w} / \mathrm{v})$, elastin $(0.5 \%, \mathrm{w} / \mathrm{v})$, chitin $(0.5 \%, \mathrm{w} / \mathrm{v}), \mathrm{CM}-$ cellulose $(0.2 \%, \mathrm{w} / \mathrm{v})$, crystalline cellulose (Whatman no. 1 filter paper, $1 \%)$ and Tween $80(1.0 \%, \mathrm{v} / \mathrm{v})$ was tested using MA as the basal medium. Degradation of DNA was tested using DNase test agar (Difco) amended with $1.5 \%$ $\mathrm{NaCl}$. Other biochemical tests and substrate oxidation tests were carried out using API 20NE, API ZYM, API 50CH test strips (bioMérieux) and Biolog GN2 microplates (Biolog) by inoculating the cells into the ASW medium. The following antibiotics were tested using the diffusion plate method: ampicillin $(10 \mu \mathrm{g})$, chloramphenicol $(25 \mu \mathrm{g})$, erythromycin $(15 \mu \mathrm{g})$, gentamicin $(10 \mu \mathrm{g})$, kanamycin $(30 \mu \mathrm{g})$, penicillin $\mathrm{G}(10 \mu \mathrm{g})$, rifampicin $(50 \mu \mathrm{g})$, streptomycin $(10 \mu \mathrm{g})$, tetracycline $(30 \mu \mathrm{g})$ and vancomycin $(30 \mu \mathrm{g})$. The DNA G $+\mathrm{C}$ content was determined using the HPLC method (Mesbah et al., 1989).

Cellular fatty acid methyl esters (FAME) of strains IMCC $1412^{\mathrm{T}}$ and $K$. algicida KCTC $8814 \mathrm{P}^{\mathrm{T}}$ were extracted

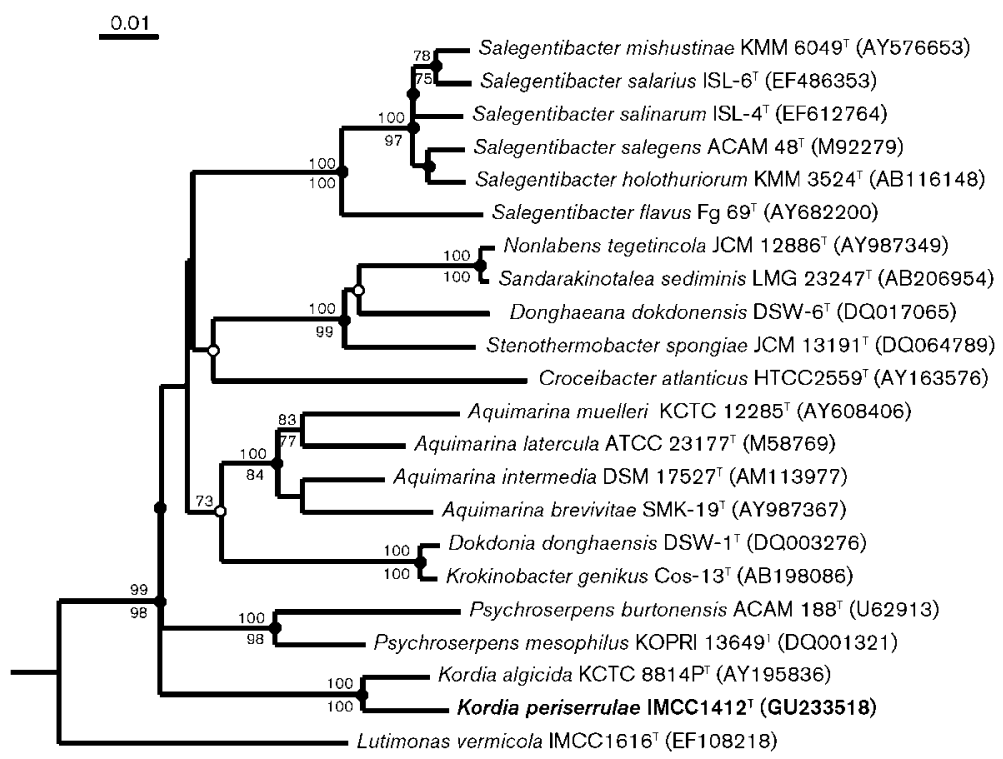

Fig. 1. Neighbour-joining phylogenetic tree, based on 16S rRNA gene sequences, showing the relationship between strain IMCC $1412^{\top}$ and its relatives in the family Flavobacteriaceae. Bootstrap values $(>70 \%)$ from both neighbour-joining (above nodes) and maximumparsimony (below nodes) are presented. Nodes recovered reproducibly by neighbourjoining, maximum-parsimony and maximumlikelihood methods (filled circles) or by two of the three treeing methods (open circles) are indicated. Polaribacter dokdonensis DSW-5 $5^{\top}$ (GenBank accession no. DQ004686) was used as an outgroup. Bar, 0.01 substitutions per nucleotide position. 
using the Sherlock Rapid Method (MIDI, Inc.) from cultures grown on MA at $30{ }^{\circ} \mathrm{C}$ for 4 days. The Sherlock Microbial Identification System (MIDI, Inc.) version 4.5 with the database TBSA40 and version 6.1 with the databases TSBA60 and RTSBA60 were used to assign GC peaks to each fatty acid. Isoprenoid quinones were extracted by TLC according to Minnikin et al. (1984) and analysed by using HPLC (Collins, 1985). Polar lipids were extracted by an integrated approach and determined using two-dimensional TLC on silica gel thin layers (Minnikin et al., 1984). The TLC plates were developed in chloroform/methanol/water $(65: 25: 4$, by vol.) in the first direction, followed by chloroform/methanol/acetic acid/water $(80: 12: 15: 4$, by vol.) in the second direction. Total polar lipids were detected by spraying with $10 \%$ ethanolic molybdophosphoric acid followed by heating at $150{ }^{\circ} \mathrm{C}$ for $30 \mathrm{~min}$. Specific functional group-containing lipids were detected with the following spraying reagents: the molybdenum blue reagent for phosphorus-containing lipid; ninhydrin for free amino groups; $\alpha$-naphthol for sugars; periodate-Schiff for $\alpha$ glycols and Dragendorff for quaternary nitrogen.

The phenotypic characteristics of strain $\mathrm{IMCC} 1412^{\mathrm{T}}$ are summarized in the species description and Table 1. In short, cells of strain IMCC $1412^{\mathrm{T}}$ were Gram-staining-negative, chemoheterotrophic, facultatively anaerobic, oxidase- and catalase-positive, non-motile, flexirubin-negative and appeared as yellow-pigmented rods. Table 1 shows the differential phenotypic characteristics between strain IMCC $1412^{\mathrm{T}}$ and the type strain of $K$. algicida. The two strains shared similar characteristics in their patterns of macromolecule degradation and antimicrobial agent susceptibility. However, several phenotypic differences were found between them allowing ready differentiation of strain IMCC $1412^{\mathrm{T}}$ from K. algicida KCTC $8814 \mathrm{P}^{\mathrm{T}}$ (Table 1).

The DNA G $+\mathrm{C}$ content of strain $\mathrm{IMCC} 1412^{\mathrm{T}}$ was $37.3 \mathrm{~mol} \%$. The major respiratory quinone detected was MK-6. The polar lipids of strains IMCC $1412^{\mathrm{T}}$ and KCTC $8814 \mathrm{P}^{\mathrm{T}}$ included phosphatidylethanolamine and several unknown lipids (see Supplementary Fig. S1 in IJSEM Online). The polar lipid profiles of both strains were differentiated by the presence of unknown aminolipids and an aminophospholipid. The major cellular fatty acid constituents of strain IMCC $1412^{\mathrm{T}}$ determined using MIDI version 4.5 were iso- $\mathrm{C}_{15: 0}(28.1 \%)$, iso- $\mathrm{C}_{17: 0} 3-\mathrm{OH}$ (16.3\%), iso- $\mathrm{C}_{15: 0} 3-\mathrm{OH}(11.2 \%)$ and $\mathrm{C}_{16: 1} \omega 7 \mathrm{c}$ and/or iso$\mathrm{C}_{15: 0} 2-\mathrm{OH}(12.4 \%)$ and were differentiated from those of K. algicida in the proportions of iso- $\mathrm{C}_{15: 0}$ and iso- $\mathrm{C}_{15: 1} \mathrm{~F}$ and in the presence/absence of several fatty acids (Table 2). There were huge differences in the fatty acid compositions determined by using different MIDI versions and methods, suggesting more careful consideration should be required for fatty acid profiles generated by different databases and methods. The DNA G $+\mathrm{C}$ content, isoprenoid quinone composition, polar lipid profile and predominant cellular fatty acids of strain IMCC $1412^{\mathrm{T}}$ were generally in good agreement with those of $K$. algicida, suggesting the assignment of the novel strain into the genus Kordia.
In conclusion, 16S rRNA gene sequence similarity and phylogenetic analyses, together with phenotypic characteristics, indicate that strain IMCC $1412^{\mathrm{T}}$ represents a novel species of the genus Kordia, for which the name Kordia periserrulae sp. nov. is proposed. Based on differential and additional phenotypic characteristics of strain IMCC $1412^{\mathrm{T}}$ not reported in the description of the genus Kordia by Sohn et al. (2004), an emended description of the genus Kordia is provided.

\section{Emended description of the genus Kordia Sohn et al. 2004}

The description of the genus Kordia is as given by Sohn et al. (2004) with the following amendments. Cells are obligately aerobic or facultatively anaerobic. Catalase activity is species-dependent. Requires $0.5-7.5 \% \mathrm{NaCl}$ for growth. Elastin is hydrolysed but DNA is not. The DNA $\mathrm{G}+\mathrm{C}$ content is $34-37 \mathrm{~mol} \%$. Major polar lipids include phosphatidylethanolamine, unknown aminolipids and polar lipids. The type species is Kordia algicida.

\section{Description of Kordia periserrulae sp. nov.}

Kordia periserrulae (pe.ri.ser.ru'lae. N.L. n. Periserrula a scientific generic name, Periserrula; N.L. gen. n. periserrulae of Periserrula, pertaining to a species isolated from the digestive tract of Periserrula leucophryna).

Cells are Gram-reaction-negative, chemoheterotophic, oxidase- and catalase-positive, non-motile, non-gliding, flexirubin-negative, yellow-pigmented and facultatively anaerobic. Aerobic growth is better than anaerobic growth. Cells are rod-shaped $(1.3-3.7 \times 0.4-1.0 \mu \mathrm{m})$. After 4 days incubation on $\mathrm{MA}$ at $30{ }^{\circ} \mathrm{C}$, colonies are circular, convex, shiny, have an entire margin and are $3.5 \mathrm{~mm}$ in diameter. Growth occurs at $4-37{ }^{\circ} \mathrm{C}$ (optimum, $30{ }^{\circ} \mathrm{C}$ ), pH 7.0-9.0 (optimum, $\mathrm{pH} 7.0-8.0$ ) and $0.5-7.5 \% \mathrm{NaCl}$ (optimum, $3.0 \% \mathrm{NaCl}$ ). Starch, casein and elastin are hydrolysed. Does not hydrolyse DNA, cellulose, CM-cellulose, chitin or Tween $80 . \mathrm{H}_{2} \mathrm{~S}$ is produced. Absorption spectral peaks of the pigments are observed at $451 \mathrm{~nm}$ (major peak) and $478 \mathrm{~nm}$. Positive for aesculin hydrolysis and gelatin liquefaction in API 20NE tests, but negative for nitrate reduction, indole production, glucose fermentation and activities of arginine dihydrolase, urease and PNPG ( $\beta$ galactosidase). Positive for the following enzyme activities; alkaline phosphatase, esterase (C4), esterase lipase (C8), lipase (C14), leucine arylamidase, valine arylamidase, cystine arylamidase, trypsin, $\alpha$-chymotrypsin, acid phosphatase, naphthol-AS-BI-phosphohydrolase, $\alpha$-galactosidase and $\beta$-galactosidase in API ZYM tests, but negative for $\beta$-glucuronidase, $\alpha$-glucosidase, $\beta$-glucosidase, $N$ acetyl- $\beta$-glucosaminidase, $\alpha$-mannosidase and $\alpha$-fucosidase. In API 50CH tests, acids are produced from glycerol, D-galactose, D-glucose, D-mannose, L-sorbose, L-rhamnose, $\mathrm{N}$-acetylglucosamine, amygdalin, arbutin, aesculin ferric citrate, D-cellobiose, maltose, sucrose, starch, glycogen, gentiobiose, D-tagatose and potassium 2-ketogluconate. In Biolog GN2 microplate tests, oxidizes $\alpha$-cyclodextrin, 


\section{Table 1. Differential characteristics between strain IMCC $1412^{\top}$ and $K$. algicida KCTC $8814 \mathrm{P}^{\top}$}

Strains: 1, IMCC $1412^{\mathrm{T}} ; 2$, K. algicida KCTC $8814 \mathrm{P}^{\mathrm{T}}$. All data were obtained from the present study except for the temperature and $\mathrm{pH}$ range for growth and DNA G + C content of K. algicida KCTC $8814 \mathrm{P}^{\mathrm{T}}$ (Sohn et al., 2004). +, Positive; -, negative. Both strains were Gram-staining-negative, non-motile, non-gliding, oxidase-positive and flexirubin-negative. Both strains hydrolysed starch, casein and elastin, but did not hydrolyse DNA, cellulose, CM-cellulose, chitin or Tween 80. In API 20NE tests, both strains were positive for gelatin liquefaction, but negative for nitrate reduction, indole production, glucose fermentation, arginine dihydrolase, urease and $\beta$-galactosidase activities. In API ZYM tests, both strains were positive for alkaline phosphatase, esterase (C4), esterase lipase (C8), lipase (C14), leucine arylamidase, acid phosphatase and naphthol-AS-BIphosphohydrolase activity, but negative for $\beta$-glucuronidase, $\alpha$-glucosidase, $\beta$-glucosidase, $N$-acetyl- $\beta$-glucosaminidase, $\alpha$-mannosidase and $\alpha$-fucosidase activities. In API 50CH tests, both strains were positive for aesculin ferric citrate, maltose, sucrose, starch, glycogen, D-tagatose and potassium 2-ketogluconate, but negative for erythritol, D-arabinose, L-arabinose, D-ribose, D-xylose, L-xylose, D-adonitol, methyl $\beta$-D-xylopyranoside, D-fructose, dulcitol, inositol, D-mannitol, D-sorbitol, methyl $\alpha$-D-mannopyranoside, methyl $\alpha$-D-glucopyranoside, salicin, lactose, melibiose, trehalose, inulin, melezitose, raffinose, xylitol, turanose, D-lyxose, D-fucose, L-fucose, D-arabitol, L-arabitol and potassium gluconate. In Biolog GN2 tests, both strains were positive for $\alpha$-cyclodextrin, dextrin, glycogen, $N$-acetyl-D-glucosamine, adonitol, cellobiose, i-erythritol, gentiobiose, $\alpha$-D-glucose, maltose, D-mannitol, D-mannose, raffinose, sucrose, pyruvic acid methyl ester, succinic acid monomethyl ester, citric acid, D-glucuronic acid, DL-lactic acid, quinic acid, succinic acid, L-alaninamide, L-glutamic acid, glycyl L-aspartic acid, glycyl L-glutamic acid, L-ornithine, L-proline, L-threonine, DL-carnitine, uridine, $\alpha$-D-glucose 1-phosphate and D-glucose 6-phosphate, but negative for Tween 40, Tween 80, L-arabinose, p-hydroxyphenylacetic acid, itaconic acid, sebacic acid, D-alanine, L-asparagine, L-histidine, hydroxy-L-proline, L-leucine, D-serine, L-serine, $\gamma$-aminobutyric acid, urocanic acid and inosine. Both strains were susceptible to erythromycin, rifampicin and vancomycin, but resistant to ampicillin, gentamicin, kanamycin, penicillin G, streptomycin and tetracycline.

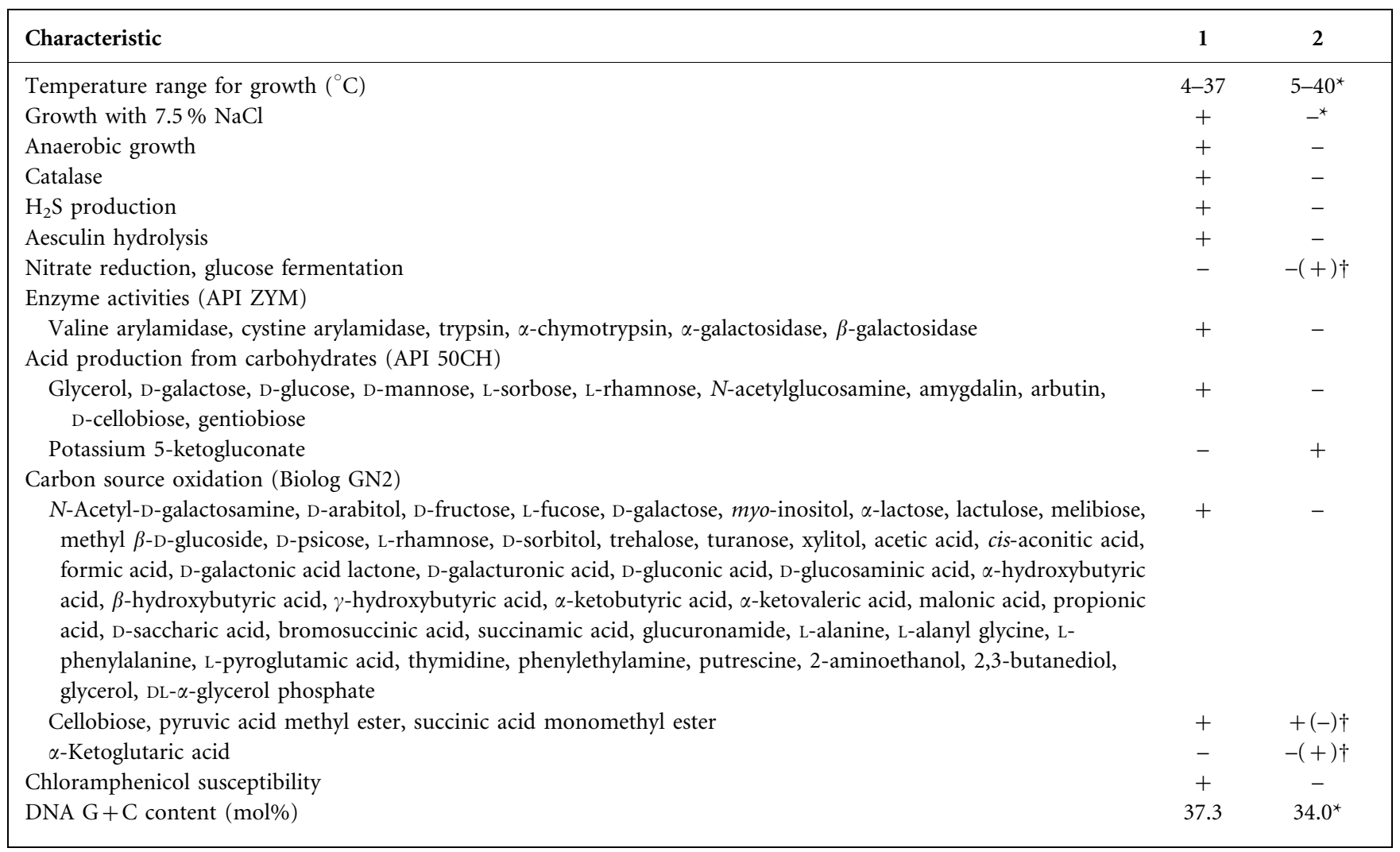

${ }^{\star}$ Data for K. algicida KCTC $8814 \mathrm{P}^{\mathrm{T}}$ obtained from Sohn et al. (2004).

$\dagger$ Conflicting results compared with the previous report (Sohn et al., 2004). The results observed by Sohn et al. (2004) are shown in parentheses.

dextrin, glycogen, $N$-acetyl-D-galactosamine, $N$-acetyl-Dglucosamine, adonitol, D-arabitol, cellobiose, i-erythritol, D-fructose, L-fructose, D-galactose, gentiobiose, $\alpha$-D-glucose, myo-inositol, $\alpha$-lactose, lactulose, maltose, D-mannitol, D-mannose, melibiose, methyl $\beta$-D-glucoside, D-psicose, raffinose, L-rhamnose, D-sorbitol, sucrose, trehalose, turanose, xylitol, pyruvic acid methyl ester, succinic acid monomethyl ester, acetic acid, cis-aconitic acid, citric acid, formic acid, D-galactonic acid lactone, D-galacturonic acid, D-gluconic acid, D-glucosaminic acid, D-glucuronic acid, $\alpha$-hydroxybutyric acid, $\beta$-hydroxybutyric acid, $\gamma$-hydroxybutyric acid, $\alpha$-ketobutyric acid, $\alpha$-ketoglutaric acid, $\alpha$-ketovaleric acid, DL-lactic acid, malonic acid, propionic acid, quinic acid, D-saccharic acid, succinic acid, bromo- 
Table 2. Comparison of cellular fatty acid composition of strain IMCC1412 ${ }^{\top}$ and $K$. algicida $\mathrm{KCTC}^{8} 814 \mathrm{P}^{\top}$, obtained using different MIDI versions and databases

Methods: M1, MIDI version 4.5 and TSBA40 database; M2, MIDI version 6.1 and TSBA60 database; M3, MIDI version 6.1 and RTSBA60 database. Values are percentages of total fatty acids and all data were generated in this study. Both strains were grown under the same culture conditions (grown on $\mathrm{MA}$ at $30{ }^{\circ} \mathrm{C}$ for 4 days). Only fatty acids representing $>1.0 \%$ of the total fatty acids are shown. tr, Traces $(<1.0 \%) ;-$, not detected.

\begin{tabular}{|c|c|c|c|c|c|c|}
\hline \multirow[t]{2}{*}{ Fatty acid } & \multicolumn{3}{|c|}{ IMCC $1412^{\mathrm{T}}$} & \multicolumn{3}{|c|}{ K. algicida КСТС $8814 \mathrm{P}^{\mathrm{T}}$} \\
\hline & M1 & M2 & M3 & M1 & M2 & M3 \\
\hline $\mathrm{C}_{15: 0}$ & 9.2 & - & - & 4.6 & - & - \\
\hline $\mathrm{C}_{16: 0}$ & $\operatorname{tr}$ & 4.7 & 1.2 & 2.4 & $\operatorname{tr}$ & 1.5 \\
\hline $\mathrm{C}_{18: 0}$ & - & 2.4 & - & 2.3 & $\operatorname{tr}$ & $\operatorname{tr}$ \\
\hline iso- $\mathrm{C}_{14: 0}$ & $\operatorname{tr}$ & - & - & 1.2 & $\operatorname{tr}$ & - \\
\hline iso- $\mathrm{C}_{15: 0}$ & 28.1 & 29.5 & 42.1 & 17.1 & 21.7 & 34.8 \\
\hline iso- $\mathrm{C}_{15: 1} \mathrm{~F}$ & 6.9 & 7.3 & 11.4 & 1.5 & 1.7 & 5.5 \\
\hline iso- $\mathrm{C}_{16: 0}$ & $\operatorname{tr}$ & $\operatorname{tr}$ & 2.1 & 1.8 & 1.6 & 2.7 \\
\hline iso- $\mathrm{C}_{16: 1} \mathrm{H}$ & - & - & - & $\operatorname{tr}$ & $\operatorname{tr}$ & 2.2 \\
\hline iso- $\mathrm{C}_{17: 0}$ & - & - & $\operatorname{tr}$ & - & - & 1.0 \\
\hline anteiso- $\mathrm{C}_{15: 0}$ & 1.4 & 1.6 & 2.1 & 1.9 & 1.5 & 2.5 \\
\hline anteiso- $\mathrm{C}_{17: 0}$ & - & - & - & 1.8 & - & $\operatorname{tr}$ \\
\hline $\mathrm{C}_{15: 1} \omega 6 c$ & - & - & $\operatorname{tr}$ & 2.1 & 1.6 & 3.2 \\
\hline $\mathrm{C}_{17: 1} \omega 6 c$ & - & - & - & 1.1 & 1.2 & 3.2 \\
\hline $\mathrm{C}_{15: 0} 2-\mathrm{OH}$ & $\operatorname{tr}$ & 1.1 & 1.6 & 1.2 & 1.0 & 1.4 \\
\hline $\mathrm{C}_{15: 0} 3-\mathrm{OH}$ & - & 1.3 & - & - & - & - \\
\hline iso- $\mathrm{C}_{15: 0} 3-\mathrm{OH}$ & 11.2 & 10.9 & 8.5 & 12.3 & 14.4 & 8.8 \\
\hline iso- $\mathrm{C}_{16: 0} 3-\mathrm{OH}$ & 5.3 & 4.5 & 3.9 & 6.9 & 7.1 & 4.6 \\
\hline iso- $\mathrm{C}_{17: 0} 3-\mathrm{OH}$ & 16.3 & 16.4 & - & 17.8 & 24.1 & 8.0 \\
\hline iso- $\mathrm{C}_{17: 1} \omega 9 c$ & - & - & $\operatorname{tr}$ & 3.7 & - & - \\
\hline $\mathrm{C}_{17: 0}$ cyclo & - & - & 1.2 & - & - & - \\
\hline \multicolumn{7}{|c|}{ Summed features ${ }^{\star}$} \\
\hline 3 & 12.4 & $14.1 \dagger$ & $20.7 \dagger$ & 8.0 & $10.8 \dagger$ & $6.2 \dagger$ \\
\hline 4 & - & - & - & 2.0 & 1.6 & - \\
\hline 5 & - & - & - & 4.0 & $\operatorname{tr}$ & - \\
\hline 9 & - & $\operatorname{tr}$ & $\operatorname{tr}$ & - & 4.4 & 7.3 \\
\hline
\end{tabular}

${ }^{\star}$ Summed features represent groups of two or three fatty acids that cannot be separated by the Microbial Identification System. Summed feature 3 contains $\mathrm{C}_{16: 1} \omega 7 c$ and/or iso- $\mathrm{C}_{15: 0} 2-\mathrm{OH}$, summed feature 4 contains iso- $\mathrm{C}_{17: 1} \mathrm{I}$ and/or anteiso- $\mathrm{C}_{17: 1} \mathrm{~B}$, summed feature 5 contains $\mathrm{C}_{18: 2} \omega 6,9 c$ and/or anteiso- $\mathrm{C}_{18: 0}$, summed feature 9 contains $\mathrm{C}_{16: 0}$ 10-methyl and/or iso- $\mathrm{C}_{17: 1} \omega 9 c$.

$\dagger$ For methods M2 and M3, summed feature 3 contains $C_{16: 1} \omega 7 c$ and/or $C_{16: 1} \omega 6 c$.

succinic acid, succinamic acid, glucuronamide, L-alaninamide, L-alanine, L-alanyl glycine, L-glutamic acid, glycyl L-aspartic acid, glycyl L-glutamic acid, L-ornithine, L-phenylalanine, L-proline, L-pyroglutamic acid, L-threonine, DL-carnitine, uridine, thymidine, phenylethylamine, putrescine, 2-aminoethanol, 2,3-butanediol, glycerol, DL- $\alpha$ glycerol phosphate, $\alpha$-D-glucose 1 -phosphate and D-glucose 6-phosphate. Susceptible to erythromycin, rifampicin, chloramphenicol and vancomycin, but resistant to ampicillin, gentamicin, kanamycin, penicillin $G$, streptomycin and tetracycline. The major cellular fatty acids are iso- $\mathrm{C}_{15: 0}$, iso- $\mathrm{C}_{17: 0} 3-\mathrm{OH}$, iso- $\mathrm{C}_{15: 0} 3-\mathrm{OH}$ and $\mathrm{C}_{16: 1} \omega 7 c$ and/or iso$\mathrm{C}_{15: 0} 2-\mathrm{OH}$ (by MIDI 4.5). The major respiratory quinone is MK-6. Polar lipids consist of phosphatidylethanolamine, unidentified aminolipids and unidentified polar lipids.

The type strain, IMCC $1412^{\mathrm{T}}$ (=KACC $14311^{\mathrm{T}}=$ KCTC $22801^{\mathrm{T}}=$ NBRC $106077^{\mathrm{T}}$ ), was isolated from a marine polychaete (Periserrula leucophryna) inhabiting a tidal flat of Donggum Island, Korea ( $\left.37^{\circ} 34^{\prime} 47^{\prime \prime} \mathrm{N} 126^{\circ} 30^{\prime} 57^{\prime \prime} \mathrm{E}\right)$. The DNA G $+\mathrm{C}$ content of the type strain is $37.3 \mathrm{~mol} \%$.

\section{Acknowledgements}

This study was supported by the Korea Research Foundation Grant (MEST, Basic Research Promotion Fund, KRF-2008-521-C00263), by the 21C Frontier Program of Microbial Genomics and Applications from the MEST, and by the project on survey and excavation of Korean indigenous species from the National Institute of Biological Resources (NIBR).

\section{References}

Bernardet, J.-F. \& Nakagawa, Y. (2006). An introduction to the family Flavobacteriaceae. In The Prokaryotes: a Handbook on the Biology of Bacteria, 3rd edn, vol. 7, pp. 455-480. Edited by 
M. Dworkin, S. Falkow, E. Rosenberg, K. H. Schleifer \& E. Stackebrandt. New York: Springer.

Bernardet, J.-F., Nakagawa, Y., Holmes, B. \& Subcommittee on the taxonomy of Flavobacterium and Cytophaga-like bacteria of the International Committee on Systematics of Prokaryotes (2002). Proposed minimal standards for describing new taxa of the family Flavobacteriaceae and emended description of the family. Int J Syst Evol Microbiol 52, 1049-1070.

Cho, J.-C. \& Giovannoni, S. J. (2003). Parvularcula bermudensis gen. nov., sp. nov., a marine bacterium that forms a deep branch in the $\alpha$ Proteobacteria. Int J Syst Evol Microbiol 53, 1031-1036.

Choo, Y.-J., Lee, K., Song, J. \& Cho, J.-C. (2007). Puniceicoccus vermicola gen. nov., sp. nov., a novel marine bacterium, and description of Puniceicoccaceae fam. nov., Puniceicoccales ord. nov., Opitutaceae fam. nov., Opitutales ord. nov. and Opitutae classis nov. in the phylum 'Verrucomicrobia'. Int J Syst Evol Microbiol 57, 532-537.

Chun, J., Lee, J. H., Jung, Y., Kim, M., Kim, S., Kim, B. K. \& Lim, Y. W. (2007). EzTaxon: a web-based tool for the identification of prokaryotes based on $16 \mathrm{~S}$ ribosomal RNA gene sequences. Int J Syst Evol Microbiol 57, 2259-2261.

Collins, M. (1985). Analysis of isoprenoid quinones. Methods Microbiol 18, 329-366.

Felsenstein, J. (1981). Evolutionary trees from DNA sequences: a maximum likelihood approach. J Mol Evol 17, 368-376.

Fitch, W. M. (1971). Toward defining the course of evolution: minimum change for a specific tree topology. Syst Zool 20, 406-416.

Jukes, T. H. \& Cantor, C. R. (1969). Evolution of protein molecules. In Mammalian Protein Metabolism, pp. 121-132. Edited by H. N. Munro. New York: Academic Press.

Ludwig, W., Strunk, O., Westram, R., Richter, L., Meier, H., Yadhukumar, Buchner, A., Lai, T., Steppi, S. \& other authors (2004). ARB: a software environment for sequence data. Nucleic Acids Res 32, 1363-1371.
Mesbah, M., Premachandran, U. \& Whitman, W. B. (1989). Precise measurement of the $\mathrm{G}+\mathrm{C}$ content of deoxyribonucleic acid by highperformance liquid chromatography. Int J Syst Bacteriol 39, 159167.

Minnikin, D. E., O’Donnell, A. G., Goodfellow, M., Alderson, G., Athalye, M., Schaal, A. \& Parlett, J. H. (1984). An integrated procedure for the extraction of bacterial isoprenoid quinones and polar lipids. J Microbiol Methods 2, 233-241.

Saitou, N. \& Nei, M. (1987). The neighbor-joining method: a new method for reconstructing phylogenetic trees. Mol Biol Evol 4, 406425 .

Sohn, J. H., Lee, J. H., Yi, H., Chun, J., Bae, K. S., Ahn, T. Y. \& Kim, S. J. (2004). Kordia algicida gen. nov., sp. nov., an algicidal bacterium isolated from red tide. Int J Syst Evol Microbiol 54, 675-680.

Stackebrandt, E. \& Goebel, B. M. (1994). Taxonomic note: a place for DNA-DNA reassociation and $16 \mathrm{~S}$ rRNA sequence analysis in the present species definition in bacteriology. Int J Syst Bacteriol 44, 846849.

Swofford, D. L. (2002). PAUP*: Phylogenetic analysis using parsimony (and other methods), version 4. Sunderland, MA: Sinauer Associates.

Tindall, B. J., De Vos, P. \& Trüper, H. J. (2008). Judicial Commission of the International Committee on Systematics of Prokaryotes; XIth International (IUMS) Congress of Bacteriology and Applied Microbiology. Minutes of the meetings, 23, 24 and 27 July 2005, San Francisco, CA, USA. Int J Syst Evol Microbiol 58, 1737-1745.

Wayne, L. G., Brenner, D. J., Colwell, R. R., Grimont, P. A. D., Kandler, O., Krichevsky, M. I., Moore, L. H., Moore, W. E. C., Murray, R. G. E. \& other authors (1987). International Committee on Systematic Bacteriology. Report of the ad hoc committee on reconciliation of approaches to bacterial systematics. Int J Syst Bacteriol 37, 463-464.

Yang, S.-J. \& Cho, J.-C. (2008). Gaetbulibacter marinus sp. nov., isolated from coastal seawater, and emended description of the genus Gaetbulibacter. Int J Syst Evol Microbiol 58, 315-318. 